\title{
THE EMBODIMENT OF EFFICIENCY-JUSTICE PRINCIPLE IN INDONESIAN RETAIL REGULATIONS
}

\author{
Edwin Tulandi ${ }^{1}$, Prof. Dr Suhariningsih ${ }^{2}$, Dr. Sihabudin ${ }^{3}$ and BambangWinarno ${ }^{4}$ \\ ${ }^{1}$ Doctoral Candidate, Law Faculty, Brawijaya University \\ ${ }^{2}$ Law Faculty, Brawijaya University \\ ${ }^{3}$ Law Faculty, Brawijaya University \\ ${ }^{4}$ Law Faculty, Brawijaya University
}

Email: edwinstevenedwin@yahoo.com

Submitted: 2017-03-27| Accepted: 2017-08-29

\begin{abstract}
Retail regulations is one of national sector which is impacted by globalization on the legal aspects in Indonesia. The dynamics of the traditional retail (traditional market and mom and pop store) management in some areas tend to have an orientation on increasing local revenue which can be seen in the management of irregular traditional market management and transition of traditional market to the private sector. On the other hand, the proliferation of modern retail which is side by side with traditional retail is a form of arrangement that is not in accordance with the retail 's designation/purpose. This indicates that the efficiencyjustice principle that aims to create a balance turns more to the efficiency of the exclusion of justice for traditional retail. This paper aims to analyze the embodiment of Efficiency-Justice Principle in Indonesian Retail Regulations. The method used in this research is normativejuridical method, which analyze existing national retail regulations. It proposes appropriate method in embodying Efficiency-Justice Principle in Indonesian Retail Regulations.
\end{abstract}

Keywords: Efficiency-Justice Principle, Retail Regulations, Modern Retail, Traditional Retail

\section{INTRODUCTION}

One of the serious problems we face in the economic development of Indonesia is the legal framework and constitutional practice in the development of economic policies. Suitable and updated legal framework will support economic development. This is based on the globalization and liberalization that began entering various aspects and life of the nation.
Globalization is not a new phenomenon, but it is the result of a long process that comes from the interaction of various factors such as advances in communications technology and transportation, the spread and the propagate of capitalism, the political victory or neoliberal New Right group, and the hegemony of science. ${ }^{1}$ Positive and negative effects also appear along with the roots of globalization and the supporting factors start

${ }^{1}$ Budi Winarno, Melawan Gurita Neoliberalisme, (Jakarta : Erlangga, 2010), 56. 
sticking in in regulation and Indonesia's government policy. One of its positive impacts of the liberalization of the economy is the increase in trade performance. But it should be remembered that trade liberalization is not as smooth as imagined, as most countries experienced economic damage systematically. Regionalism in trade is perhaps preferable, for instance the ASEAN's arrangement in economic regionalism, which later known as ASEAN Economic Community (AEC). While such regionalism requires certain preparation for affected countries, such arrangement move states parties towards better economic development. The impact is their exclusion or expulsion process against certain economic actors are thrown as a result of the liberal $^{2}$. Moreover, economic liberalization may lead to social inequality if it does not regulate correctly. Exclusion of the economic agents as a result of liberalization can be seen from the elimination of traditional retailers in the retail industry.

Many Indonesian people are included in the retail industry, especially those belonging to the category of small and medium-sized enterprises (SME). In its development, these small vendors dominating the number of workers in the retail industry in Indonesia. These vendors then turned into merchant in traditional

${ }^{2}$ http://indef.or.id/id/berita/detail/551/dampak-positifdan-negatif-liberalisasi-ekonomi-menurut-ekonomindef. diakses tanggal 15 maret 2016. 146 markets. Grocery store's merchant even get into the retail informal industry, they become one kind of vendors called street vendors (Ind: pedagang kaki lima). The emergence of these vendors is a matter that can not be avoided due to the rapid population growth each year, but it does not offset the growth of employment. ${ }^{3}$

The placement of modern retail market that competes with traditional markets is not appropriate way to be done. The competition that happens supposed to be a competition between modern retail versus modern retail industry, or traditional retail industry versus traditional retail industry. The problem arises when there is a modern retailer who takes part in the traditional market life so the customers from traditional market are also being targeted by modern retail market. Almost all traditional market turnovers have decreased to $75 \%{ }^{4}$ The phenomenon of modern retailers which take part in the life of traditional markets is a global phenomenon that triggered by the liberalization of foreign capital investment and occured in almost every country. According to Readon, the market share of modern retail in food commodities in South Korea, Thailand, Mexico, Poland, and Hungary, has reached more than $50 \%$. Meanwhile, it has reached around 70-85\%

\footnotetext{
${ }^{3}$ Positioning Paper Ritel, 2010, Jakarta, 4.

${ }^{4}$ Dedie S. Martadisastra, Persaingan Usaha Ritel Modern dan Dampaknya Terhadap Pedagang Kecil Tradisional, Jurnal Persaingan Usaha, (Komisi Pengawas Persaingan Usaha, Edisi 4, 2010), 68.
} 
Brazil and Argentina, and it has reached around $70-85 \%$ in West Europe. Readon warned that the market share of one-third to one-half by the modern retail is very prone to incur the potential costs of economic, social and cultural. ${ }^{5}$

Efficiency-Justice Principle is a part of the principles in the administration of the economy based on economic democracy. The Efficiency-Equity Principle is included in the Constitution of the Republic of Indonesia Year 1945. So then as a consequence the Efficiency-Equity Principle should be the basis of efficiency in the implementation of the economy of Indonesia.

Retail regulations regulate traditional retail and modern retail which contains the relationship to the central and local government. It also addresses the problems of retail as well as the rights and obligations of traditional retail and modern retail. Retail Regulation is referred to the Law No. 7 of 2014 about Commerce, Law No. 20 Year 2008 on Micro, Small and Medium Enterprises and the Presidential Decree No. 112 Year 2007 on Management and Development of Traditional Markets, Shopping Centers and Modern Stores. Minister of Trade Regulation No. 70 Year 2013 on the Management and Development

\footnotetext{
${ }^{5}$ Ninuk Rahayuningrum dan Tjahya Widayanti, Kajian Dampak Ekonomi Terhadap Keberadaan Hypermarket Terhadap Ritel/Pasar Tradisional, (Jakarta: Pusat Litbang Perdagangan Dalam Negeri dengan PT IDEF Iramadani, ), 2014.
}

of Traditional Markets, Shopping Centers and Modern Stores.

The presence of this retail regulations did not dispel concerns about the exclusion of traditional retail. The imbalance between efficiency and equity in the application of the Efficiency-Equity Principle in the various regions are often felt by traditional retailers. This happens due to the orientation of retail regulations in more areas leads to efficiency simply by ignoring the values of justice. The effect of globalization encourages most local government to further increase own-source reveneu (OSR) by allowing modern retailers are flourishing in the region without explicit permission (retail bulging) and it doesn't compensate with the increase of empowerment of the traditional retail, both the local markets and/or traditional markets.

Based on the background described above, this paper aims to analyze the embodiment of Efficiency-Justice Principle in Indonesian Retail Regulations

\section{LEGAL MATERIALS AND METHODS}

This type of research is classified into normative research or legal research literature. The emphasis of this research is using a legal substance, not the data so that the primary data used is merely to strengthen, equip and support. Secondary 
data sources is accessed through a data source library (library research), which consists of primary legal materials and secondary law.

The approach used in the study problem is of course adjusted to the subject matter which is the focus of research. This study used three approaches: philosophycal approach, statute approach, and conceptual approach.

\section{RESULT AND DISCUSSION}

\section{Efficiency-Justice Principle as a Part} of the Economy Enforcement Based on Economic Democracy.

Economic Democracy can be found in Article 33 Paragraph (4) of the Constitution of Republic Indonesia which states: "National economy organized based on economic democracy with the principles of togetherness, efficiency-equity, sustainability and environmental insight, independence and by keeping a balance between progress and unity national economy".

According to Mohammad Hatta, economic democracy is the sovereignty of the people which is seen as an ideal of "genuine democracy" of Indonesia. He explained further that Indonesia's democracy was supposed to be a continuation of a genuine democracy in Indonesia. "Genuine democracy" of Indonesia itself contains: i) the ideals that live in the hearts of the Indonesian people from ancient times to the present and did not escape because of the oppression of the various form; ii) the ideals of past protests, which is the right to argue with the general way of all state regulations that are deemed unfair (the basis of the demands in order to get the freedom of movement and assembly of the people); iii) ideals of helping. The genuine democracy of Indonesia contains two characters: i) the first character is to take decisions by consensus is the foundation of political democracy, ii) the second character is mutual help and mutual cooperation is a good principle to enforce economic democracy. $^{6}$

The dynamics of the international economic and national push the changes to the enforcement of economy of Indonesia.. As a reaction in overcoming the economic developments without leaving the noble values of "Genuine Democracy" of Indonesia, the Economic Democracy juxtaposed with principles which based on the noble values of "Genuine Democracy" of Indonesia. Those principles are referred to in Article 33 Section (4) of the Constitution of the Republic of Indonesia Year 1945 which are: i) the principles of togetherness; ii) the efficiency-equity; iii) sustainable; iv) environmental; v) independence, vi);

\footnotetext{
${ }^{6}$ Mohammad Hatta, Demokrasi Kita (pikiran-pikiran tentang demokrasi dan kedaulatan rakyat), (Jakarta: Sega Arsy, 2014), 39.
} 
balanced progress; vii) the unity of the national economy.One of the principles of economy democratic is the EfficiencyEquity Principle. Efficiency is closely related to competition, because it can be said that the rivalry or competition can drive or be able to embody the efficiencies. A competition is a condition where the businessmen are trying to be as effective as possible to allocate resources.

Competition aims to ensure the efficient use of resources and motivating a number of potential available. Competition can be both positive and negative implications.. From the positive side, competition may encourage businesses to use resources optimally. While the negative implication is to run a competition for free (free fight liberalism) and negative behavior in Law No. 5 of 1999 on Monopoly and Unfair Competition as prohibited behavior that includes activities that are prohibited and banned agreement.

Regarding to the efficiency itself, Mubyarto stated that the pursuit of efficiency has its limits in the form of moral restraints, not a technical limitation.. How do we put the limit of moral boundary? Moral boundaries can be held if we could be sincere. This prompted economic justice. Economic justice appear to be a problem in the community if people start to worry (concern) that the atmosphere of competition in the economy and the business community to walk in a way that justice is disturbed or it gets harder to embody it in their lives. The realization of social justice depends on the implementation of the principle of economic justice. Economic justice is the rule, while social justice is the consequent feeling of security and peace in the community because the rules adhered to by all members of society without exception. Advanced and modern society as an ideal society is a society that can maintain a balance between continuous progress through the efforts of efficiency and peace for the realization of justice. For the sake of progress and peace of society, both economic justice and efficiency elements have the similar important position. $^{7}$

Mubyarto's opinion represents the reason why the word efficiency paired with the word equity into the efficiency-equity. Be aware that the movement of the economy of Indonesia will not grow if it does not carry out the efficiency as well as possible, but as a result, the values of justice in society will be eliminated as a result of the limited efficiency. Therefore, to achieve the objective of the Constitution of the Economy of Indonesia in the form of general welfare, the efficiency of which emphasize competition must be balanced with social justice, the balance between competitors (businesses) and cooperation,

\footnotetext{
${ }^{7}$ Mubyarto, Sistem dan Moral Ekonomi Indoensia, (Jakarta: LP3ES, 1994), 114.
} 
which on the one hand as a competition and on the other side as a justice.

\section{a. Efficiency Principle of Justice} Application in Retail Management

Retail development in counties is facing with management and arrangement that is not suitable and parallel with efficiency principle of justice, public market management as a part of national retail should managed by micro, small, and middling agency, but in reality it were managed by Local Revenue Offices, public market that should have become one of the national economic backbone is helpless because it just have been seeing as source of income without existence of reciprocal. As a result, it public market was always be ignored. One of the alternative which have practiced in several counties is by switch to private management, but with considering private management profit orientation, this is not a correct decision by seeing how expensive the stall rental price.Beside the problem of public market management, retail management in counties is also have related problem. Based on President's Rule number 112 year 1007 about Traditional Market, Shopping Centre and Modern Store article 3 clause 1 state" "establishment of Shopping Centre and Modern Store must refer to the spatial planning of the district/city and detailed plan of district/city spatial planning, that also include zoning plan"
The existence of Rencana Tata Ruang Wilayah ((Spatial Plan) RTRW) or Rencana Detail Tata Ruang Wilayah ((Detailed Spatial Plan) RTDRW) and Zoning Regulation is requirement from central government to regional government to give permit to retail businessman so they can do their business. However, seeing facts in the field that until now not all of the regions have RTRW or RTDTW and zoning plan. But in condition of many modern retail that even stand next to the traditional retail, shows lack of government intervention dealing with retail problem.

Retail management and arrangement just as described above, shows the imbalance of efficiency principle of justice in retail management where the term efficient in this case is shown by disregard the value of justice to traditional retail. If this will be applied in retail arrangement, then what kind of efficiency and justice that should exist to create balance as the purpose of efficiency principle of justice.

\section{b. Efficiency in Perspective of Business Competition}

Efficiency relates with use of resources, which mean human, machine, raw material, and other materials was used to produce biggest possible output. Thus there no input that useless or in vain. Efficiency today also means that products and services that being produced is judged highly by consumer so where their choice 
were not distorted. Efficiency in future will obtained and from incentive for innovation that increase product quality and service even in improvement in production process. Increase of production with low cost, as innovation that will produce new, better products and services. Productive use of resources will give consequence in bigger output, then will give bigger economic growth and wealth to the nation. Lower price will give consumer higher income then will spend it in other transaction, investment, or for savings. Total of surplus or wealth from consumer and producer get bigger. Thus policy to control competition will help business reach their beneficial goal to the society that will increase total surplus in the future ${ }^{8}$

Business competition scene will not materialize with acts of anti-business competition. Business scene that grow playing field level is a healthy competition. In level playing field there are three equalities: (1) Equal opportunity, means equal business chance to where there is no discrimination. (2) Equal accessibility, where there are no businessmen who are being banned to enter the market. For example: there is no businessmen who banned to get bank credit. The important point here is every of them who got the opportunity was through the healthy business competition process. (3) Equal

\footnotetext{
${ }^{8}$ Andi Fahmi Idris dkk, Hukum Persaingan Usaha Antara Teks dan Konteks, (Jakarta: GTZ, 2009), 17.
}

treatment, that is government treat every businessman equally.

In level playing field retail context there must be no wrong understanding, with giving equal chance between modern retail and traditional retail that is by give modern retail variety of facilities, equal treatment is necessarily apply to give equal chance to fellow modern retail. If it was given to both of the retails equally it will result in traditional retail collapse. Retail modern with their market power should not get equal treatment with traditional one, but level playing field related with equal treatment in competition perspective were reserved for traditional retail and traditional retail, modern retail and modern retail.

c. Empowerment Traditional Retail and Retail Equitable Arrangement

\section{Empowerment Traditional Retail}

Law empowerment is a concept and purpose. As a process, law empowerment covers the use of law to increase life standard for group of people who are unlucky through combination of education and action. As one purpose, law empowerment is a real achievement by the group in increasing their life standard through law. ${ }^{9}$

\footnotetext{
9 Bank Pembangunan Asia, 2000, Pemberdayaan Hukum Untuk Meningkatkan Tata Pemerintahan Yang Baik Dan Mengurangi Kemiskinan, (Jakarta: The Asia Foundation Sembrani Aksara Nusantara, 2000), 10.
} 
Law empowerment is highly related with justice, because it makes the unlucky group as centre of their attentions. Thus, the hindrance that make they can't develop can be get rid by build a law system that can be allow them to develop and independent.Discussion related with this, about people to get partisanship has delivered many times by John Rawls in his book Theory of Justice, he had an argumentation on human who have been rational in their "original position" that they will have two principle of justice. According to him, the first principal state that every people have right on the most extensive system of basic freedom that have fair proportion with similar system for other people. Second principal state; (a) evenly spread in terms of social and economic is fair if it is benefiting the most unfortunate people in society and ;(b) attached to open positions and offices for everyone. ${ }^{10}$

Empowerment always refers to unfortunate group in society that frequently becomes a victim of economic development especially in this globalization era. This was experienced by traditional retail whether it using public market facility or using traditional stall. Therefore, ideal empowerment model to traditional retail is to rest on them

\footnotetext{
${ }^{10}$ Pan Mohamad Faiz, 'Teori Keadilan', (2009) v. 6, n 1, Jurnal Konstitusi, 135.

Empowerment process gradually can be done by three phase; 1) Initial phase; 2) Participatory process; 3) Emancipatory process. ${ }^{11}$ These three phases is highly relevant if applied to traditional retail empowerment. Initial phase is empowerment phase by government to the people, participatory phase is empowerment phase by government with the people, and for emancipatory phase is empowerment phase for the people by the people. These phases were because in harmony with family value that become a basic of Indonesian economy, where that joint ventures done not just by people, in this case traditional retail, but it also need togetherness of every nation element from government, businessmen and the people itself.

Initial phase, empowerment in this phase put crucial role to the government because in this phase the people is passive, that what has been planned will be implemented by the people. Therefore, government planning should make the economic constitution as the foundation in every policy that will be taken. It also relevant with how to maximize each provincial potential without abandoning the values that have outlined in Indonesian Economic Constitution. Empowerment in

\footnotetext{
${ }^{11}$ Masykuri Bakri, Dekonstruksi Jalan Terjal Pembangunan Negara Dunia Ketiga Perspektif Pendidikan, Pemberdayaan, dan Pelayanan Publik, (Surabaya: Visi Press Media), 2011, 47.
} 
this phase is to emphasize to how build conducive business climate to retail industry, business climate can grow by;

a. Traditional retail funding, funding for them can be one of the problem that have made traditional retail have difficulty to progress and develop, in order to make them still exist funding access is needed. Government in this case become funding facilitator to traditional retail through their funding institution with make ease of the credit requirement.

b. Revitalization, all this time image of slump and dirty from traditional retail have become problems to traditional retail that use public market. Thus, development or rejuvenation (revitalization) of unfeasible public market is needed. Public market revitalization that empowering is emphasize interest of businessmen of public market, not interest of political elite or other interest in the name of nation or efficiency mask. In empowering revitalization, public market displacement must be based on result of discussion with related businessmen, not based on unilateral regional government decision. This also applied public market construction which needs dialogue to be in tune with family value based on joint ventures of related side (government, businessmen, and the people) that use the facility.

c. Partnership, empowering traditional retail besides it needs government's help, it also needs help of the third party, and the solution is partnership.

d. Trade promotion, in some regions, it is found out that one of the reasons why the public market is difficult to improve is because the citizen do not have the right to promote the trade, while the promotion is a form of government's concern and acknowledgement towards the existence of public market, it is realized that not all of public market can show their uniqueness which exhibit its regional specialties, so it is slipped form government's concern, this is the thing which makes public market is difficult to improve.

Participatory phase, a process of empowerment that comes from the Government together with the society, and reserved for people. In the context of retail, empowerment is carried out by the government, which in this case the local government together with the traditional retail businessmen. The empowerment in this phase is related with the traditional retail management and the forming of associations to attract the businessmen, with various government policies on the first phase then continued to this phase which is how the local government becomes the 
manager (for public market) also the manager supervisor (for public market managed by private) or even becomes the management supervisor facilitator (for traditional food stall) traditional retail.

Emancipatory phase, this is the last phase where the empowerment process comes from people to people featured with government and society supports. In the context of retail, this phase is about how traditional retail builds trust for society thus they can shop in traditional retail.

\section{Retail Arrangement}

Arrangement Retail is one instrument in realizing the protection of justice for Retail Traditionally, if viewed with the theory of legal protection according to Satjipto Rahardjo, that in traffic in the interests of no interests colliding therefore by to safeguard the interests of the one done by limiting interest another, and if it is associated with John Rawls's theory of justice related to the second priority of justice, which is the first principle of equality (the same freedom) applies in advance of the second principle the principle of distinction.

Based on the second theory was that if it is associated with the retail that restrictions interests by modern retail should not be done by prohibiting modern retail to strive or standing in an area, as opposed to the first priority in a theory of justice of John Rawls, thus restrictions to modern retail is done in the perspective of spatial planning is not restricted in meaning in decline but the restrictions in the sense in governance.

Dynamics of policies by local governments, which until now will be full of injustice is felt by traditional retailers. Structuring often justifying the exclusion of the traditional retailers either by means of public market trading and those that use traditional means of trading stalls.

Injustice for traditional retailers can clearly be seen from the presence of modern retail side by side (with a very close distance) with traditional retail. This can lead to a decrease in profit resulted traditional retailers out of business. The problem of distance, which for most areas did not even set the ideal distance between traditional retail and modern retail, it is also coupled with the emergence of modern retail bulging as if in spite of surveillance by local authorities.

In the context of the retail arrangement does not mean denial or restriction for modern retailers to be able to get into areas, because rather than rejected or restricted it is not appropriate and in line with the principles of efficiency, as well as justice for modern retail, and therefore the arrangement of a solution in developing traditional retail and modern retail together. 
Fair arrangement is directed on the definition of Democracy Economic System, which are Pro Poor, Pro Job, and Pro Growth. Its implementation will be applied on the arrangement planning.

Pro poor in retail context is the alignment on traditional retail, retail arrangement which takes side on traditional retail is meant to make the traditional retail as the center of concern. It means when organizing retails then the traditional retail is not the one which should adapt with the invation of modern retail, but it supposed that the modern one which has to fit the traditional retail instead. But, modern retail development in districts instead shows evictions and displacement of public market under the name of revitalisation which often occured. The same thing also dirasakan by the traditional shops (warung) which are helpless due to the development of modern retail.

Pro Job in retail means to buld retail as seen from the capacity of retail in a certain industry called Retail Industry. By looking through the industrial context, the existences of traditional dan modern retail become a unity. Retail industry existence can emerge job vacancies, this is because estimatedly the retail industry do not need special skills as the requirements. Retail industry can also present the diverse patterns of service toward consument (society) for social and cultural traditional retail, and for modern retail featured with its efficiency and effectiviness presents a service pattern that developed in accordance with times.

Pro Growth, the clarification of spatial planning known by the appearance of urban spatial planning, and commonly, the urban spatial planning is always identified as the physical planning alone, namely an overview of city, parks, residential buildings, office buildings and other planning. However, by the rapid time development, a physical planning may not be appropriate anymore because there are more than just a physical plannning in forming urban planning.

There should be a control following the retail planning and utilization. Thus, based on Article 1 Point 15 of The Law of Republic of Indonesia Number 26 Year 2007 regarding Spatial Management, Spatial Management Control is an effort to realize an order of the spatial use. There are five instruments or devices in implementing spatial utilizaiton control namely; the determination of zoning regulations, permits, incentives \& disincentives and the imposition of sanctions. All those instruments will be organized by the local government as the authority.

1. Zoning Regulations, Zone is an area or a region which has specific environment characteristics and functions. Therefore, it can be ascertained that a zone is having a certain identity or characteristic 
that is different from other area. While Zoning is a regional division into several zones in accordance with the original function and characteristics or directed for other functions development. Zoning regulation can be defined as a regulation which organize clarification, notation and codification of basic zones, terms of use, construction rules and procedures of development implementation. Zoning regulation is one of device in plannning spatial of a certain area, in which the spatial plan of the area has macro to micro plans level. Zoning regulation can also be functionalized as the controller of an area and city development implementation there it can be done precisely; a) Operational device of spatial utilization control; b) Reference in giving permission for traditional dan modern retail c) .Reference in giving incentives and isincentives; d) Reference in the imposition of sanctions toward retailer who violates the regulations; e) As the reference in developing and using an area in purpose of retail.

2. Licensing, according to Ateng Syafrudin, licensing is distinguished into 4 types, which are; a) Permission, for the purpose of eliminating obstacles, allowing the prohibited one, rejection toward permission that needs limited formulation; b) Dispensation, to break through the obstacles that formally prohibited. Therefore dispensation is a special case.; c) Licence, is a permission given to a company in order to organize some activities; d) Concenssion, is a permission connected with a serious work related to public interest that supposed to be the government's duty, but the work is granted by the government to the concessioner who is not from government official. It could take a form of contractual or combination or license featured with some status awarding with its rights and obligations and also some certain requirements. Based on the explanation of Article 37 Subsection 1 The Law of Republic of Indonesia Number 26 Year 2007 regarding Spatial Management, Licensing is about the one related with spatial utilization permission in which according to the Law regulations, it has to be owned before implementing the spatial utilization. The permission referred here is the location permission/spatial function, space envelope and spatial quality. In the context of spatial management, lisencing is the form of spatial management control in district and municipality area. The licensing mechanism naturally aims to; a) Controlling some certain activities; b)Preventing harmful impact on enviroment; c)The motivation of protecting certain objects; d)Distributing limited objects. Licensing in retail 
arrangement begins from point $\mathrm{C}$ in the aims of licensing, which is the motivation of protecting certain objects. Certain objects referred here is the traditional retail, while the motivation of protecting certain objects is based on retail spatial management plan which is pro poor, pro job and pro growth as it becomes the description of Economic Democracy.

3. Incentives and Disincentives. The devices of spatial management control is needed to embody the proper spatial planning. As referred in Article 38 Spatial Management Law Number 20 Year 1999 regarding Spatial Management, the instruments used here are Incentives and Disincentives. Incentive is a device or an effort of giving rewards toward an implementation of activity that is parallel with spatial management namely; a) tax relief, compensation, cross subsidization, rewarding, spatial rent, and stock participating; b) infrastructure procurement and development; d) easiness of licensing procedures; and/or; d) presenting reward to society, private and/or local government. Disincentive as mentioned in Article 35, is a device to prevent, limit the growth, or reduce the activity that is not in line with the spatial management plan, namely: a) a high tax imposition which is adapted with the cost required to overcome the impact cause by the spatial utilization; b) and/or infrastructure provision restrictions, compensation imposititon, and penalty. The direction of incentive imposition for traditional retail is in the form of; a) Tax relief; b) Infrastructure procurement and development on public market trading facility; c) Easiness in licensing process. The direction of incentive imposition for modern retail is in the form of award for obedient modern retail. The direction of disincentive imposition for traditional retail in the form of penalties for traditional retail that ignore its surrounding in business. The directions of disincetive for modern retail are in the form of; a) higher tax; b) restriction for infrastructure provision; compensation; d) applying incentive. Incentive and disincentive are the directions referred by local government in retail management. Disincentive is not only applied on modern retail but also for traditional retail. Therefore, the spatial used by the traditional retail will be protected too. Disintecsive for modern retail is a form of prevention toward the diminished traditional retail as the impact of competition among modern retail.

4. Sanctions Imposition, which is one of the spatial control effort. It is intended to be an enforcement action over the spatial usage that is not in accordance with the 
spatial plan and zoning. The imposition of sanctions is not only given for unsuitable spatial utilization, but also for the government authorities who do not publish the permission in accordance with the spatial plannning. These sanction directions are the reference in impositioning sanction toward; a) unsuitable spatial use as referred from spatial structure plan and national spatial pattern; b) violation of the provision of national system zoning regulation direction; c) spatial utilization without its permission as issued from National Spatial Plan; d) unfitness spatial utilization as referred on the permission issued from National Spatial Plan; e) violation of provision stipulated in spatial utilization permission requirements issued from National Spatial Plan; f) spatial utilization that impedes the access toward the area in which as stated by the legislation, belongs to public; and/or; g) spatial utilization permission that deviates from procedure. In retail management, sanctions imposition are intended for; a) spatial utilization that unsuits the spatial pattern plan; b) the violation toward ideal distance between traditional retail and modern retail; c) the violation in stipulating the analysis of socioeconomic condition; d) Spatial utilization without any permission; e)
Spatial utilization permission deviates from licensing procedures.

\section{CONCLUSIONS AND SUGGESTIONS}

An ideal Retail arrangement is a systematically structured arrangement from the central regulations to the local one and applying Equity- Efficient Principle as the highest law.

1. Efficiency principle can be seen from the perspective of business competition. The atmosphere of business competition will not appear if there are anticompetitive actions. This healthy competition takes a form of business atmosphere that stimulates level playing field. Inside level playing field, there are several equalities namely; (1) Equal opportunity, the same business opportunity for businessmen without any discrimination. (2) Equal accessibility, where all the businessmen are fairly not prohibited to enter the market. The important thing is, for every businessmen who already have the opportunity, they have been through the healthy business competition process. (3) Equal treatment, means that government should treat every businessmen in the same way.

2. Empowerrment and Arrangement are applied as referred in the Equity Principle. The empowerment is held 
through 3 phases which are initial phase, participatory phase, and emancipatory phase. Those phases are chosen because they suit with family value that becomes the fundamental of the economy of Indonesia, in which the togetherness in business is not only held by the society, in this case the traditional retail, but also needed the from all nations' elements such as governments, businessmen, and society. Furthermore, related to arrangements as referred here, spatial arrangement for retail will be based on Pro Poor, Pro Job and Pro Growth which in the context of retail is a form of alignments toward traditional retail. A Pro Poor arrangement will make the traditional retail as the center of concern which means the modern retail should be the one that adapts with the traditional retail existence. Pro Job in the context of retail is to build retail based on the capacity in certain industry namely Retail Industry. Pro Growth, a retail arrangement planning which underlines the accomodation of each elements both socioeconomic politics and law to develop retail in the context of local and national development.

\section{REFERENCES}

\section{Journal Articles}

Kusnadi, Dedek, 'Implementasi Kebijakan Penataan Ritel Tradisional dan Modern di Kota Jambi', (2013) v.5 n.1 Jejaring Administrasi Publik.

Pan Mohamad Faiz, 'Teori Keadilan', (2009) v. 6 n. 1 Jurnal Konstitusi.

Simbolon, Freddy Pandapotan, 'The Impact of Relationship Marketing Strategy in Indonesia Retail Industry', (2016) v.7 n.2 Binus Business Review.

Solikha, Euis, 'Analisa Industri Ritel di Indonesia', (2008) v.15 n.2 Jurnal Bisnis dan Ekonomi.

Wahyuningtyas, Yuliana Sih \& Nugroho, Agung AY, 'Relevance and Key Factors og "Demand-Side Oriented Market" Analyses to Defines Indonesia's Retail Industry', (2013) v.8 n.2 Business Review.

\section{Books}

Andi Fahmi Idris dkk, Hukum Persaingan Usaha Antara Teks dan Konteks, (Jakarta: GTZ), 2009.

Bank Pembangunan Asia, Pemberdayaan Hukum Untuk Meningkatkan Tata Pemerintahan yang Baik Dan Mengurangi Kemiskinan, (Jakarta: The Asia Foundation Sembrani Aksara Nusantara), 2000.

Budi Winarno, Melawan Gurita Neoliberalisme, (Jakarta: Erlangga), 2010.

Dedie S. Martadisastra, Persaingan Usaha Ritel Modern dan Dampaknya 
Terhadap Pedagang Kecil Tradisional,

Jurnal Persaingan Usaha, (Jakarta:

Komisi Pengawas PersainganUsaha), 2010.

Ninuk Rahayuningrum dan Tjahya Widayanti, Kajian Dampak Ekonomi Terhadap Keberadaan Hypermarket Terhadap Ritel/Pasar Tradisional, (Jakarta: Pusat Litbang Perdagangan Dalam Negeri ), 2010.

Masykuri Bakri, Dekonstruksi Jalan Terjal Pembangunan Negara Dunia Ketiga Perspektif Pendidikan, Pemberdayaan, dan Pelayanan Publik, (Surabaya: Visi Press Media), 2011

Mohammad Hatta, Demokrasi Kita (pikiranpikiran tentang demokrasi dan kedaulatan rakyat), (Bandung: Sega Arsy, 2010)

Mubyarto, Sistem dan Moral Ekonomi Indoensia, (Jakarta: LP3ES, 1994)

Positioning Paper KPPU

\section{Internet}

http://indef.or.id/id/berita/detail/551/dampak -positif-dan-negatif-liberalisasiekonom menurut-ekonom-indef.

\section{Legislations}

Undang-Undang Dasar Negara Republik Indonesia 1945

Undang-Undang No 5 Tahun 1999 tentang Larangan Monopoli dan Persaingan Usaha Tidak Sehat.

Undang-Undang No.26 Tahun 2007 tentang Penataan Ruang.

Undang-Undang No. 20 Tahun 2008 tentang Usaha Mikro, Kecil dan Menengah.

Undang-Undang No. 7 Tahun 2013 tentang Perdagangan

Peraturan Presiden Republik Indonesia Nomor 112 Tahun 2007 tentang Penataan dan Pembinaan Pasar Tradisional, Pusat Pembelanjaan dan Toko Modern .

Peraturan Perdagangan Republik Indonesia Nomor 53/M-DAG/PER/12/2008 tentang Pedoman Penataan dan Pembinaan Pasar Tradisional, Pusat Pembelanjaan dan Toko Modern

Peraturan Menteri Perdagangan Republik Indonesia Nomor 70 Tahun 2013 tentang Pedoman Penataan dan Pembinaan Pasar Tradisional, Pusat Pembelanjaan dan Toko Modern 